DOI:

Юлія Роїк, аспірант Київскої державної академї декоративно-прикладного мистеитва і дизайну імені М. Бойчука

\title{
ЕТНОДИЗАЙН КЕРАМІКИ ЯК СКЛАДОВА ПРОФЕСІЙНОӤ ПІДГОТОВКИ МАЙБУТНІХ ФАХІВЦІВ ДЕКОРАТИВНО-ПРИКЛАДНОГО МИСТЕЦТВА
}

У статті розглянуто та проаналізовано проблему розвитку та подальшого дослідження етнодизайну кераміки. Підкреслено, щзо вивчення етнодизайну кераміки, як складової професійної підготовки майбутніх фахівців декоративно-прикладного мистецтвва, з урахуванням особливостей та традицій регіонів, прискорить процес відродження осередків народної кераміки в Украӥні як сучасних ичентрів художньоі культури. У праці виокремлено п'ять найважливіших аспектів етнодизайну кераміки: педагогічний, психологічний, історичний, культурологічний та фізіологічний. Подано визначення “етнодизайн кераміки”.

Ключові слова: мистецька освіта; професійна освіта; етнодизайн; етнодизайн кераміки; художникикерамісти.

Сх. 1. Табл. 1. Лім. 6.

Yuliya Royk, Postgraduate Student Kyiv Mykhaylo Boychuk State Institute of Decorative and Applied Art and Design

\section{ETHNODESIGN OF CERAMICS AS A PART OF PROFESSIONAL PREPARATION FOR FUTURE SPECIALISTS OF DECORATIVE APPLIED ART}

The article substantiates the importance of the interaction of traditions and innovations in the formation of the foundations of the new ceramic vision, and the directions of this interaction are revealed. Indicated that in order to develop the future artists of arts and crafts the true professional features can be based on principles of ethnopedagogy and of ethnodesign.

The definition of "ceramics", "ethnodesign" is analyzed. The author's concept is stated and the essence of the definition "ethnodesign of ceramics" is formulated. Ethnodesign of ceramics as a component of professional training of specialists of decorative applied art is considered. "Ethnodesign of ceramic" is: a system of organizational and pedagogical activities; artistic design of ceramic products on the basis of Ukrainian folk traditions; methodologically grounded process of transferring experience of production of forming and decorating ceramic products taking into account the innovations and regional traditions.

In the publication the author analyzes the problem of the necessity of development and further research of ethnodesign of ceramics. The article presents an algorithm of work on its solution. The state and directions of enhancement of readiness of the future artist of arts and crafts to the use the folk traditions in their creative activity are analyzed.

The paper identifies five most important aspects of ethnodesign of ceramics: pedagogical, psychological, historical, cultural and physiological. It is emphasized that the study of ethnodesign ceramics, as a component of the professional training of future specialists in decorative arts, taking into account the features and traditions of the regions, will accelerate the process of revival of folk ceramics cells in Ukraine as modern centers of artistic culture.

Keywords: an artistic education; vocational education; ethnodesign; ethnodesign of ceramics; an artist of ceramic.

П остановка проблеми. У закладах сучасної мистецької освіти ідея модернізації та націоналізації змісту фахових дисциплін набуває актуальності, адже глобалізаційні процеси, а саме прискорений розвиток науки, техніки, технологій, спричиняють занепад етнічних цінностей. Концептуальна ідея розвитку сучасної української мистецької освіти полягає у поєднанні національних традицій, народного досвіду з європейськими інноваціями. Усвідомлення важливості змін сприяє забезпеченню нової якості професійної підготовки фахівців декоративно-прикладного мистецтва. Саме це спонукає до послідовного та багатовекторного дослідження сутності понять пов'язаних із професійною підготовкою майбутніх фахівців декоративно-прикладного мистецтва.

У сучасних дослідженнях вітчизняних науковців 3 професійної педагогіки набула поширення терміносполука “етнодизайн кераміки”. Адже, сучасна освіта у вищих мистецьких навчальних закладах, має грунтуватись на культурноісторичних цінностях українського народу, його традиціях і духовності. Ключовим аспектом системності змін в національній освіті має бути гармонійна єдність традицій та інновацій. На нашу думку, потрібно всебічно пропагувати український і світовий досвід викладання гончарної справи; визначити перспективні напрями розвитку мистецтва і технології етнодизайну кераміки. 


\section{ЕТНОДИЗАЙН КЕРАМІКИЯК СКЛАДОВА ПРОФЕСІЙНОӦ ПІДГОТОВКИ}

МАЙБУТНІХ ФАХІВЦІВ ДЕКОРАТИВНО-ПРИКЛАДНОГО МИСТЕЦТВА

\begin{abstract}
Аналіз основних досліджень та публікацій. Народне мистецтво безперечно має вплив на

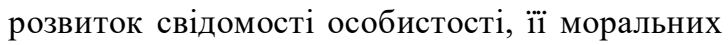
цінностей. Окреслена тематика стала предметом наукових досліджень В. Бутенка, В. Татаренка та ін. Розробку теоретичних питань художньої підготовки в цілому та у зв' язку з її предметним декоративно-прикладним спрямуванням одними 3 перших започаткували М. Бернштейн, А. Пастухов, М. Тимоненко.

Сучасний стан професійної підготовки майбутніх художників декоративно-прикладного мистецтва грунтовно викладено в публікаціях О. Власюк, В. Шимко, Л. Корницької.
\end{abstract}

Для нашого дослідження цінними є праці В. Бугенка, А. Бровченка, В. Жлудько, Л. Корницької, А. Крижанівського, Е. Муртазаєвої, Л. Оршанського [3], А. Руденченко [5], В. Тименка, Б. Тимкова [6], Ю. Легенького [2], А. Іоннікова, в яких викладено формулювання сугності поняття “етнодизайн” у контексті різних спеціальностей.

Незважаючи на наявність численних наукових досліджень 3 проблем висвітлення окремих питань етнодизайну, слід зазначити, що самостійних наукових пошуків комплексного характеру щодо порушеної проблеми нами не виявлено.

Мета та завдання статті: розглянути етнодизайн кераміки як складову професійної підготовки фахівців декоративно-прикладного мистецтва. Сформулювати сутність поняття “етнодизайн кераміки”. Акцентувати увагу на тому, що етнодизайн кераміки - це не відмова від сучасності, не повторення минулого, а опора на національні традиції, взаємозв'язок поколінь. Розкрити особливості професійної підготовки фахівців декоративно-прикладного мистецтва 3 етнодизайну кераміки.

Виклад основного матеріалу. У Національній доктрині розвитку освіти в Україні передбачено українознавчу спрямованість освіти, осучаснення змісту освіти та інтеграцію української освіти в світовий простір. Особливий інтерес викликає питання підготовки майбутніх художників декоративно-прикладного мистецтва, зокрема 3 етнодизайну кераміки. Слід враховувати те, що розвинути у майбутніх художників декоративноприкладного мистецтва риси справжнього професіонала можна спираючись на засади етнопедагогіки та етнодизайну.

Сучасна професійна мистецька освіта, зорієнтована на розвиток творчої особистості, має враховувати здобугки національної культури. А отже, професійна підготовка фахівців декоративно-прикладного мистецтва має здійснюватися на засадах етнодизайну кераміки, сутність поняття якого суттево відрізняється за різними авторами.

Вважаємо за потрібне проаналізувати ці визначення із метою виокремлення авторського поняття та сутності дефініції “етнодизайн кераміки".

По-перше, слід зазначити, слово кераміка грецького походження. Так називають вироби 3 глини та їі сумішами з іншими мінеральними додатками. Слово і поняття кераміка та похідні від них - кераміст, майстер керамічного виробництва, керамічний виріб тощо - широко відомі у світі. На жаль, менш відомі їхні українські аналоги - гончар, гончарство, гончарний виріб, гончарний круг тощо. Поняття кераміки дуже широке і складається з багатьох складових.

Так, на основі вивчення довідкової, науковопедагогічної, психологічної та мистецтвознавчої літератури нами складено таблицю зміст якої висвітлює сутність поняття “етнодизайн” (Таблиця 1).

Складне слово “етнодизайн” утворюється поєднанням двох слів - “етнічний” і “дизайн”. Дизайн це особлива проектна діяльність, що об'єднуе “художню” і “технічну” творчість. "Етно" вживається коли йдеться про народне, національне. Воно утворене від "етнос" (грец. ethnos) означає народ, стійка спільність людей, що історично склалась на певній території [4].

Таким чином, виходячи із сутності визначення поняття “етнодизайн”, викладеної нами у відомостях Таблиці 1, ми дійшли висновку, що у професійній педагогіці не існує усталеного поняття "етнодизайн”, сутність поняття істотно відрізняється за кожним автором. Виходячи 3 відомостей, викладених у таблиці 1 та на основі власного педагогічного досвіду, ми сформулювали власне визначення "етнодизайну кераміки".

Отже, етнодизайн кераміки - комплексне, багатоаспектне поняття, що являє собою:

- систему організаційно-педагогічних заходів (викладена нами у схемі 1), зорієнтована на особистісний розвиток, метою і кінцевим результатом якого має стати готовність до виконання професійної діяльності;

- художнє проектування керамічних виробів на основі українських народних традицій, використаня здобутків народних майстрівгончарів кожного регіону України;

- методологічно обгрунтований процес передачі досвіду виробництва формотворення і декорування керамічних виробів з урахуванням інновацій та регіональних традицій.

Разом 3 тим, етнодизайн кераміки охоплює 


\section{Сутність етнодизайну за авторами}

\begin{tabular}{|c|c|}
\hline Автор & Визначення \\
\hline А. Іонніков & $\begin{array}{l}\text { Етнодизайн - виявлення особливостей організації функцій, специфічне } \\
\text { поєднання матеріалів та особливих прийомів ї обробки, спосіб розкриття } \\
\text { характерного для національної психології ставлення до ландшафту та } \\
\text { організації штучного середовища. }\end{array}$ \\
\hline Ю. Легенький & $\begin{array}{l}\text { Етнодизайн - нова парадигма бачення складного комплексу народної, } \\
\text { ремісничої та професійної культури [2]. }\end{array}$ \\
\hline Л. Оршанський & $\begin{array}{l}\text { Етнодизайн розглядається як проектна діяльність зі створення сучасних форм } \\
\text { матеріального середовища } з \text { використанням традиційних елементів культури } \\
\text { певного етносу. Етнічний дизайн відповідає змістовим та естетичним } \\
\text { характеристикам конкретної етнокультури, використовує національний } \\
\text { колорит, характерний для традицій того чи іншого народу. Етнодизайн } \\
\text { розглядається як проектна діяльність зі створення сучасних форм матеріального } \\
\text { середовища } 3 \text { використанням традиційних елементів культури певного етносу. } \\
\text { Етнічний дизайн відповідає змістовим та естетичним характеристикам } \\
\text { конкретної етнокультури, використовує національний колорит, характерний для } \\
\text { традицій того чи іншого народу [3]. }\end{array}$ \\
\hline А. Руденченко & $\begin{array}{l}\text { Етнодизайн - педагогічно доцільно організований процес передачі попередніми } \\
\text { поколіннями наступним регіонального досвіду художнього проектування } 3 \\
\text { урахуванням автентичних особливостей формотворення } \mathrm{i} \text { декорування } \\
\text { предметного довкілля [5]. }\end{array}$ \\
\hline В. Тименко & $\begin{array}{l}\text { Етнодизайн - це напрям формотворення та фігуротворення навколишнього } \\
\text { середовища в етнічному стилі. }\end{array}$ \\
\hline
\end{tabular}

різні аспекти: педагогічний, психологічний, культурологічний, історичний та фізіологічний. Розглянемо їх детальніше.

Педагогічний аспект слід розглядати в єдності дидактичної та виховної складових. Сутність дидактичної складової варто розглядати у реалізації двоєдиної навчальної діяльності: організації теоретичного навчання і продуктивної праці у процесі практичної діяльності. Отже, педагогічна складова передбачає такі заходи:

- добір раціональних форм і методів професійного навчання й розробленої 3 урахуванням психофізіологічних особливостей учнів навчально-виробничих робіт 3 художньої кераміки;

- контроль за якістю виробів художньої кераміки;

- розробка комплексу навчально-методичного та матеріально-технічного забезпечення;

- розробка переліку конкретних видів трудової діяльності, які дають змогу набути навички роботи 3 матеріалами, інструментами, обладнанням при виготовленні робіт 3 художньої кераміки.

У процесі теоретичного навчання художники декоративно-прикладного мистецтва мають здобути знання про матеріали, які використовуються для виготовлення виробів, їх обробку і декорування, призначення, організацію праці. Особлива увага має приділятись засвоєнню знань і уявлень про мистецтво української регіональної художньої кераміки, його історію та роль у житті людей.

У процесі реалізації програми необхідно використовувати наступні методи: бесіда, демонстрація, вправи на закріплення прийомів, практичні роботи репродуктивного і творчого характеру, методи мотивації і стимулювання, навчального контролю, екскурсії в музеї, галереї, участь у виставках та фестивалях декоративноприкладного мистецтва.

Історичний аспект. Проблема професійної підготовки фахівців декоративно-прикладного мистецтва, зокрема художників-керамістів, $є$ однією 3 найактуальніших проблем сучасної освіти в України. Адже недаремно Україну називають “країною глини” і наприкінці XIX початку XX ст. на наших землях існувало понад 700 осередків народної кераміки. Найвідоміші з них - Адамівка, Дибинці, Опішня, Косів, Ічня, та багато інших. На жаль, більшість із них припинили своє існування, проте здобутки і вміння народних умільців мають стати надбанням сучасного декоративно-прикладного мистецтва, предметом вивчення науковців.

Історія українського гончарства має глибоке коріння, але про діяльність гончарних цехів на території сучасної України, ми дізнаємось у XV ст., саме в цей час удосконалюються виробничі 


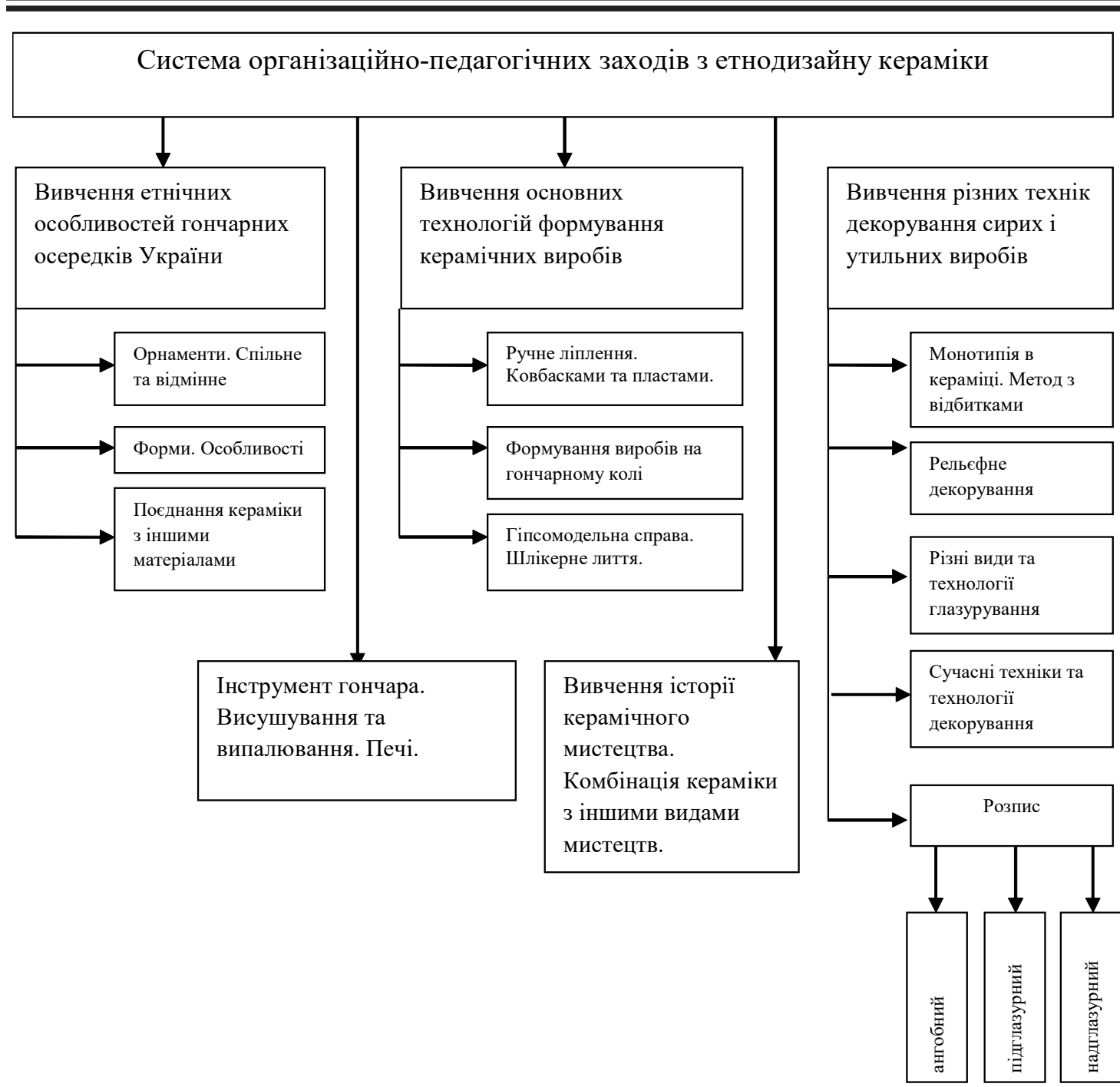

Схема 1. Система організаційно-педагогічних заходів з етнодизайну кераміки

техніки, розповсюджуються посуд з поливою. У XVI ст. було запроваджено поетапну систему професійної підготовки майстрів, закріплену документально цеховими статутами. Зацікавлені подальшим розвитком гончарного промислу земства, громадські організації, приватні особи почали направляти найбільш здібних молодих гончарів на короткочасне стажування до відомих керамічних підприємств, в гончарні майстерні, показові пункти (Товсте, Берлинці-Лісові, Опішне, Глинськ, Постав-Мука, Нова Водолага, Олешня, Дибинці). Вони мали навчально-виробничий характер: їхні майстри виготовляли кераміку й одночасно вчили цьому учнів із числа кустарів. Саме з випускниками цих шкіл пов'язане активне впровадження в українському гончарстві кінця XIX - першої чверті XX ст. нових форм посуду, нових орнаментальних систем, пошуки нових стильових змін і пристосування виробів до новітніх потреб часу. Проте, у 1920 - 1930-ті роки багато керамічних навчальних закладів припинили своє існування, українське гончарство поволі занепадає.

Отже, історичний аспект етнодизайну кераміки передбачає грунтовне вивчення становлення i розвитку гончарної справи на різних історичних іiї етапах 3 метою вивчення традиції створення гончарних виробів та вироблення свого власного особливого стилю їх декорування, а також із урахуванням особливостей та надбань кожного керамічного осередку України.

Культурологічний аспект передбачає збереження та примножування традиційної ідентичності України, формування національного стилю мислення в молодого покоління фахівців декоративно-прикладного мистецтва, що $є$ необхідною передумовою інтелектуального розквіту нації, відродження архаїчного, забутого. 


\section{ЕТНОДИЗАЙН КЕРАМІКИЯК СКЛАДОВАПРОФЕСІЙНОЇ ПІДГОТОВКИ}

МАЙБУТНІХ ФАХІВЦІВ ДЕКОРАТИВНО-ПРИКЛАДНОГО МИСТЕЦТВА

Завдяки керамічній образній мові, студенти мають можливість глибше пізнати історію рідного краю, свого народу, України.

Психологічний та фізіологічний аспекти. Декоративно-прикладне мистецтво, а отже i кераміка, $\epsilon$ джерелом духовного розвитку особистості. Його дія на людину невичерпна за своїми можливостями, багатством та універсальністю, воно має вплив на психічну діяльність, формує та розвиває почуття, моральні та естетичні ідеали, творче мислення та науковий світогляд. Праця з природнім матеріалом добре впливає на здоров'я людини, на гармонізацію психологічного стану та самопочуття будь-якої особистості, на відновлення ДНК коду людини, iіi розуміння світу через глину.

Завдяки навчальній програмі з етнодизайну кераміки та створенню потрібного освітнього середовища, кожен студент-художник матиме можливість залучитись до матеріальної культури суспільства, сформувати естетичний смак, гармонізувати свій психологічний стан та емоційне сприйняття навколишньої дійсності, розвивати фантазію, творчу уяву, асоціативне мислення, образне мислення, зорову пам'ять, сенсормоторні якості. Будуть формуватись та удосконалюватись знання, уміння та навички 3 перетворення навколишнього світу та грунтовні теоретичні, практичні вміння з етнодизайну кераміки. Кераміка є чудовим підгрунтям для розвитку творчого потенціалу, для формування художнього та естетичного смаку.

У кераміці можливо виконувати як декоративні композиції, так і тематичні, сюжетні твори, поєднувати площинні та об'ємні форми, використовувати необмежену колірну гаму та різноманітні художні фактури.

Національний досвід, традиції народних майстрів, творчо перероблені в умовах професійного навчання, допоможуть майбутнім художникам-керамістам виготовляти неповторні, естетичні вироби та твори мистецтва, що матимуть не лише художню, а й національну цінність. Адже традиція не є догмою, вона не заперечує розвиток, а стимулює потребу в новаторстві, що супроводжує традиційне мистецтво народу і свідчить про його постійне оновлення, збагачення і поглиблення [1].

Етнодизайн кераміки стане “опорною точкою”, “точкою відправлення” для новітніх тенденцій розвитку даного ремесла, сміливих та вдалих експериментів, нового бачення матеріалу.

Слід проводити грунтовне дослідження історії розвитку гончарного ремесла у тій чи іншій місцевості, здійснювати аналіз творів 3 виявленням формотворчих та художньостилістичних особливостей.

Викладене вище свідчить, що етнодизайн кераміки як складова професійної підготовки майбутніх фахівців декоративно-прикладного мистецтва в закладах вищої мистецької освіти 3 урахуванням окреслених аспектів у такий спосіб, щоб його результати стали не тільки метою для створення матеріальних і духовних цінностей, а й засобом освіти й виховання художниківкерамістів, закріпленням, поглибленням і розширенням набутих ними професійних знань.

Висновки та перспективи подальшого розвитку. Таким чином, нами розглянуто та визначено сутність дефініції “етнодизайн кераміки” як складової професійної підготовки фахівців декоративно-прикладного мистецтва, комплексне, багатоаспектне поняття, що являє собою: систему організаційно-педагогічних заходів; художнє проектування керамічних виробів на основі українських народних традицій, використання здобутків народних майстрівгончарів кожного регіону України; методологічно обгрунтований процес передачі досвіду виробництва формотворення і декорування керамічних виробів з урахуванням інновацій та регіональних традицій.

Водночас етнодизайн кераміки як складова професійної підготовки майбутніх фахівців декоративно-прикладного мистецтва в закладах вищої мистецької освіти має враховувати такі аспекти: педагогічний, психологічний, історичний, культурологічний, фізіологічний з метою не тільки створення матеріальних і духовних цінностей, а й засобом освіти й виховання художниківкерамістів, закріпленням, поглибленням і розширенням набутих ними професійних знань.

Проведений аналіз літературних та наукових джерел дає підстави для висновку про те, що новаторські напрями в роботі з традиційним матеріалом і експерименти в організації сучасного інтер'єрного та екстер'єрного середовищ спричинять появу цілого ряду цікавих творів художньої кераміки, що становитимуть вагоме надбання вітчизняного мистецтва XXI ст., a отже $\epsilon$ актуальними для подальшого вивчення.

\section{ЛІТЕРАТУРА}

1. Антонович Є. А. Декоративно-прикладне мистецтво: навч. посіб. для студ. пед. ін-тів / Є. А. Антонович, Р.В. Захарчук-Чугай, М. С. Станкевич // - Львів: Світ, 1992. - 270 с.

2. Легенький Ю. Культурологічна модель дизайну / Юрій Легенький // Технічна естетика і 
дизайн: наук.-техн. зб. / Укр. асоц. прикладної геометрії. - К., 2001. - Вип. 1. - С. 9 - 28.

3. Оршанський Л. В. Декоративно-ужиткове мистецтво та етнодизайн - традиції і сучасність у художньо-трудовій підготовці майбугніх учителів трудового навчання / Л.В. Оршанський // Инновационные образовательные технологи. 2000. - № 1. - С. 77-82.

4. Професійна освіта: словник: навч. посіб. / [уклад. С. У. Гончаренко, І. А. Зязюн, Н. Г. Ничкало, О. С. Дубинчук, Н. О. Талалуєва, А. О. Молчанова, Л. Б. Лук'янова; за ред. Н. Г. Ничкало] - К.: Вища шк., 2000. - 381 c.

5. Руденченко А. А. Теоретичні і методичні засади навчання етнодизайну студентів у вищих мистецьких навчальних закладах [Текст] автореф. дис. д-р пед. наук спец.: 13.00.02 - теорія та методика навчання (технічні дисципліни) / А. А. Руденченко// Нац пед. ун-т ім. М. П. Драгоманова. - Київ, 2017. - 42 с.

6. Тимків Б. М. Роль етнодизайну у підготовці художників декоративно-прикладного мистецтва / Б. М. Тимків // Наукові записки Терн. нац. пед. у-ту ім. В. Гнатюка. - 2011. - №3 -С. 44 - 49.

\section{REFERENCES}

1. Antonovych, Ye. A. (1992). Dekoratyvnoprykladne mystetstvo [Decorative Applied art]. Tutorial for students. Lviv: Svit, 270 p. [in Ukrainian].

2. Lehenkyi, Yu. (2001). Kulturolohichna model dyzainu. Tekhnichna estetyka $i$ dyzain [Culturological model of design. Technical aesthetics and design]. Kyiv, vol.1., pp. 9 - 28. [in Ukrainian].

3. Orshanskyi, L. V. (2000). Dekoratyvnouzhytkove mystetstvo ta etnodyzain - tradytsii $i$ suchasnist u khudozhno-trudovii pidhotovts maibutnikh uchyteliv trudovoho navchannia [Decorative and applied arts and ethno design - the traditions and modernity in the artistic and labor training of future teachers of labor education]. Journal, no. 1, pp. 77-82. [in Ukrainian].

4. Honcharenko, S. U., Ziaziun, I. A., Nychkalo, N. H., Dubynchuk, O. S., Talaluieva, N. O. et al., (2000). Profesiina osvita [Professional education]. Dictionary, tutorial. Kyiv: Vyshcha shkola, 381 p. [in Ukrainian].

5. Rudenchenko, A. A. (2017). Teoretychni i metodychni zasady navchannia etnodyzainu studentiv u vyshchykh mystetskykh navchalnykh zakladakh [Theoretical and methodological principles of teaching ethno-design students in higher educational institutions]. Extended abstract of Doctor's thesis. Kyiv, 42 p. [in Ukrainian].

6. Tymkiv, B. M. (2011). Rol etnodyzainu u pidhotovtsi khudozhnykiv dekoratyvno-prykladnoho mystetstva [The role of ethno design in the preparation of artists of decorative and applied arts]. Scientific notes of $V$. Hnatyuk Ternopil National Pedagogical University, no.3, pp. 44-49. [in Ukrainian].

Стаття надійшла до редакції 19.10.2018

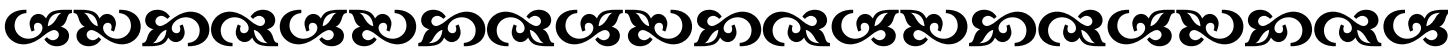

"TТе, що найвипробувапіший мудрещь знає і дотримується, є тільки думкою... Я вивчав себе самого."

Теракліт

давньогрецький білособ

“Фля того, щоб бормувати розумні харақтери в індивідуума, яктвориів постійно розвивається, процвітаючого і назавжди щасливого суспільства, қожен з ранніх років повинен бути привчаємий до щоденної қорисної роботи, та його силам $і$ здібностям.

Роберт Оуен

валлійсъжий білособ, педагог

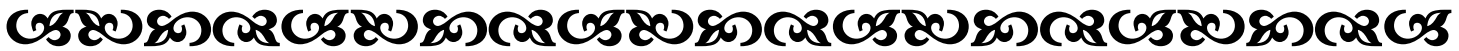

\author{
Використано джерела мудрості \\ Книга вражень 1906-1910 pp. - IP НБУВ. - Ф-I. - № 775. - С.250. \\ Джерело: http://dovidka.biz.ua/tsitati-ta-aforizmi-pro-sport-ukrayinskoyu/ \\ Джерело: http://dovidka.biz.ua/vislovi-pro-vihovannya/ Довідник цікавих фактів та \\ корисних знань () dovidka.biz.ua \\ взято 3 :http://pro-status.com.ua/citaty/5/365_5.php
}

